\title{
SIMULATION OF MANUFACTURING CELLS WITH UNRELIABLE MACHINES
}

\author{
Elleuch, M.; Masmoudi, F.; Ben Bacha, H. \& Maalej, A. Y. \\ Mechanical Engineering Department, National School of Engineers of Sfax (ENIS), Sfax, Tunisia \\ E-Mail: faouzi.masmoudi@enis.rnu.tn
}

\begin{abstract}
Cellular manufacturing is an application of a group technology used to improve the performance of manufacturing systems. A number of factors, including vulnerability to machine breakdown, under utilization of resources and eventual unbalanced workload distribution in a multi-cell plan disturb the smooth working of the factory when using the group technology concept.

This paper focuses on a manufacturing cell composed of unreliable machines. We are interested in the problem of cell production availability facing unexpected circumstances due to an internal perturbation caused by machine breakdown. We consider a policy of intercellular transfer in the event of breakdown to improve the availability of the cells. We examine through simulation the performance of the system and evaluate the intercellular transfer policy in terms of some selected criteria. The results indicate, under the assumed conditions, that the developed policy improves the performance of the production cells.

(Received in November 2005, accepted in August 2006. This paper was with the authors 2 months for 1 revision.)
\end{abstract}

Key Words: Manufacturing Cell, Machine Breakdown, Intercellular Transfer, Simulation, Performance Measures

\section{INTRODUCTION}

Cellular manufacturing, an application of group technology, focuses on the creation of manufacturing cells in which a number of part families are manufactured. A cell consists of a set of functionally dissimilar machines which are placed in close proximity to one another and dedicated to the manufacture of a set of parts [1]. This grouping of functionally dissimilar machines is what differentiates cellular manufacturing from the traditional job-shop layout "called a functional layout" in which machines with similar processing functions are grouped together. A part family, in this context, is a set of parts which are similar in terms of processing requirements.

A number of factors, including vulnerability to machine breakdown, under utilisation of resources and eventual unbalanced workload distribution in a multi-cell plan, pose some problem when using the group technology concept [2]. Taking into account the machine breakdown, the random failing consequence on the cellular shop performance is more serious than on the functional shop performance. Indeed, production cells formed of dissimilar machines do not insert any redundant machines. Therefore, equipment that breakdown, generates the interruption of the whole cell. This leads to the partial deterioration of the performance of the total system [3]. Generally, a sudden breakdown has a meaningful effect on the cost of operation and maintenance, on the dissatisfaction of customers and on the total production [4, 5, 6]. Therefore, the application of an efficient strategy against these perturbations permits to improve the performance of these production systems.

Most of previous research, has focused on cellular manufacturing system, and treated problems concerning the formation of cells in a dynamic environment without considering the 
process of machine deterioration and the impact of breakdowns which disturb the smooth working of the factory $[7,8,9]$. Little research was interested in minimizing the effect of breakdowns on the performance of production cells. Some works discussed the efficient maintenance policies to improve the performance and the availability of the cellular manufacturing $[3,10]$. Others developed new coefficients of similarity which consider a number of alternative ways during the machine breakdown [11]. [12] and [13] used the analytical approach based on Markov chains for the modelling of the availability of manufacturing cells. The analytical model proved that the intercellular transfer in case of breakdown improves the cell availability. However, to test several patterns describing a variation of production parameters, the analytical model becomes very complex. For that, one makes resort to the simulation.

In this study we are interested in the control of manufacturing cells to improve the overall system performance in terms of regular performance measures such as flow time, throughput, and machine utilization. We discuss a comprehensible simulation study that tests various solutions of intercellular transfer and their impact on the performance of manufacturing cells. This solution is based on the external routing flexibility: the ability to release parts to alternative cells.

The rest of this paper is organized as follows: Section 2 provides characteristics of manufacturing cells. In section 3 we formulate a comprehensive idea of intercellular transfer policy. Section 4 details the model of cellular manufacturing, and a discussion of results is presented in Section 5. Finally, we recapitulate in Section 6 the main conclusions of this work and we make recommendations for future research.

\section{MANUFACTURING SYSTEM FEATURES}

The shop consists of seven machines that are grouped into two different group technology cells (a) and (b). The former contains three dissimilar machines, while the second contains four dissimilar machines. A typical example of this manufacturing system is shown in Fig.1.
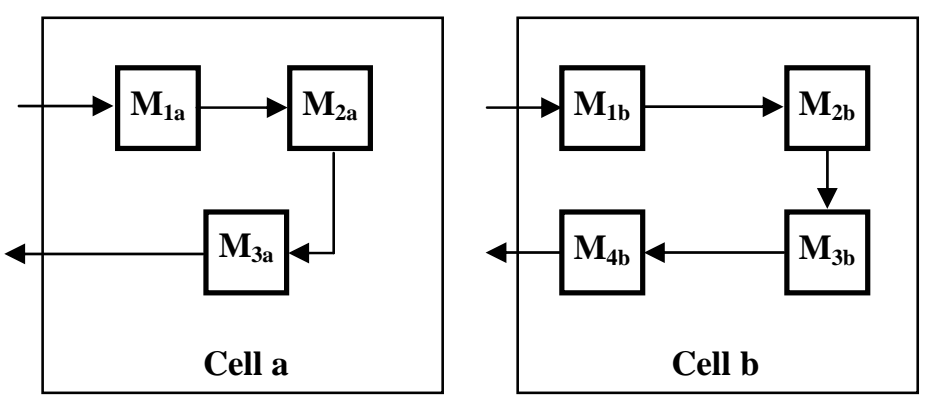

Figure 1: Manufacturing cell layout.

This cellular manufacturing system operates under the following considerations:

- The production system in this study is composed of independent cells operating in a static environment.

- The production system does not possess any intermediate buffer between workstations. In addition, its feeding in raw material or in semi-finished products is always possible.

- All queue disciplines are First In First Out "FIFO”.

- Every production cell permits the manufacture of a product family having several types presenting the different production batches. Any batch put in production must be finished entirely before launching another. We assume that the order for batch arrival is cyclic,

- A transfer batch size of one part is used between machines in the cell. That is, when each part in a batch is completed on a given machine it is sent ahead to the subsequent machine 
in its routing regardless of whether the other parts in the same batch have completed processing at the given machine.

The following assumptions about the failure/repair process of machines are made:

- We use the exponential probability density function for modelling machine breakdowns. Then, we assume that the distribution of times before failures follows an exponential law of constant parameter breakdown rate. In the event of failure, breakdown repair times are assumed to be exponentially distributed. We signal that Breakdown repair service begins immediately after a breakdown occurs.

- A machine can fail only while performing an operation and when a breakdown occurs. The incomplete job is set aside until the machine is repaired, if no standby equipment is provided. Once repaired, the machine completes processing this task before the next job is selected from queue. No scrap or rework results from a machine breakdown.

\section{DESCRIPTION OF INTERCELLULAR TRANSFER POLICY}

The failure of only one machine in the cellular manufacturing system can disrupt the product flow in the whole system. Indeed, this failure is going to generate the interruption of the other machines in the corresponding cell. It implies a reduction of the machine utilization rate, a reduction of the production capacity and a dissatisfaction of customers. To overcome these problems, several solutions have been applied in order to improve the operational availability of the system. These solutions can be grouped in two big strategic categories [3]:

- Strategies that have the tendency to reduce the frequency of breakdowns, as the preventive maintenance and predicted maintenance.

- Strategies that have the tendency to reduce the severity of breakdowns by the prediction of an alternative solution during the repair, as the routing flexibility, the redundancy and the intermediate buffer.

In the case of some maintenance policies, standby machine is provided as a mean for alternate output during the breakdown and repair of primary equipment. The standby machine operates until the primary machine is repaired. Consequently, in this study we are interested in a solution based on the external routing flexibility. This solution has the tendency to apply a strategy that permits to reduce the severity of the failure by the application of an intercellular transfer policy in case of breakdown of a machine in the cell. Indeed, for a production cell treating a type of product, the breakdown of a workstation should not imply the interruption of the production in this cell. Sometimes the continuity of the production will be assured by the transfer of the product flow toward a neighbouring cell admitting an inactive machine able to treat this product type. By this action, it will be possible to continue the process of manufacturing during of the breakdown. The cell will be formed by workstations that are in a working state of the first cell and the standby machine of the second cell. It is worth noting that in the case of the unavailability of the standby machine, the production in the first cell will be interrupted until the failing machine is repaired.

It is necessary to note that the realization of intercellular transfer can bring advantages at the level of performance of the system if we consider some parameters such as the transfer duration, the inactivity delay of the standby machine and the repair duration.

In this survey, we considered these assumptions:

- We assume that the movement time and setup time to the standby machine is insignificant,

- The team of maintenance is able to act against the multiple breakdowns in the same module (main machine and standby machines).

We note that it consists of a simple transfer or double transfer depending on whether we have only one or two redundant machines for a principal machine. 


\section{MODELLING OF CELLULAR MANUFACTURING}

The simulation helps to analyze the different solutions and to choose the best one to detect problems and to identify those representing causes and those representing effects. It permits to have a real representation of the system and to analyze its performance, to visualize the effect of the system following the uncertain changes and to examine the modification or the implementation of new policies of piloting or provision for a given system. In this section, the modelling and the simulation of the cellular production system are achieved with the ARENA software [14]. The latter permits to describe the physical entities and the work of a production shop.

To conduct our simulation we defined first the problem and stated our objectives. The problem facing cellular manufacturing is the effect of machines breakdown.

The objectives of this study were to determine if the intercellular transfer is a solution and if it solves the problem. For evaluating the performance of our model under the various policies, we select the productivity of the cell, presented in the number of produced pieces, and machine utilization rate as performance criteria.

We consider the system shown in the Fig. 1. Cell (a) is constituted of three different machines dedicated to the manufacturing of two product types. Cell (b) is formed of four different machines capable to manufacture three product types. Table I shows the product data. Time is measured in minutes.

Table I: Product data.

\begin{tabular}{|c|c|c|c|c|c|c|}
\hline & $\begin{array}{c}\text { Product } \\
\text { type }\end{array}$ & $\begin{array}{c}\text { Batch } \\
\text { size }\end{array}$ & $\begin{array}{c}\text { Pro } \\
\text { oper }\end{array}$ & $\begin{array}{l}\text { essin } \\
\text { tion }\end{array}$ & $\begin{array}{l}\text { time } \\
\text { sequ }\end{array}$ & $\begin{array}{l}\text { and } \\
\text { nces }\end{array}$ \\
\hline \multirow{3}{*}{ Cell a } & & & \multicolumn{4}{|c|}{$\mathbf{M}_{1 \mathrm{a}} \quad \mathrm{M}_{2 \mathrm{a}} \quad \mathrm{M}_{3 \mathrm{a}}$} \\
\hline & 1 & 19 & \multicolumn{2}{|c|}{19} & \multicolumn{2}{|c|}{13} \\
\hline & 2 & 30 & \multicolumn{2}{|c|}{--- } & & 9 \\
\hline \multirow{4}{*}{ Cell b } & & & $\mathrm{M}_{1 \mathrm{~b}}$ & $\mathrm{M}_{2 \mathrm{~b}}$ & $\mathrm{M}_{3 \mathrm{~b}}$ & $\mathrm{M}_{4 \mathrm{~b}}$ \\
\hline & 3 & 16 & 14 & 11 & --- & 13 \\
\hline & 4 & 25 & 16 & --- & 14 & 11 \\
\hline & 5 & 20 & --- & 17 & 13 & 7 \\
\hline
\end{tabular}

The mean time between failures (MTBF) and the mean time to repair (MTTR) of each machine are shown in Table II.

Table II: MTBF and MTTR of each machine in the system.

\begin{tabular}{|l|c|c|c|c|c|c|c|}
\hline Machine & $\mathbf{M}_{\mathbf{1 a}}$ & $\mathbf{M}_{\mathbf{2 a}}$ & $\mathbf{M}_{\mathbf{3 a}}$ & $\mathbf{M}_{\mathbf{1 b}}$ & $\mathbf{M}_{\mathbf{2 b}}$ & $\mathbf{M}_{\mathbf{3 b}}$ & $\mathbf{M}_{\mathbf{4 b}}$ \\
\hline MTBF & 6000 & 3500 & 3000 & 5500 & 4000 & 3500 & 6500 \\
\hline MTTR & 500 & 420 & 350 & 400 & 400 & 360 & 380 \\
\hline
\end{tabular}

In this survey, the batches arrival is considered cyclic. Indeed, the manufacturing of a new batch is only permitted if the previous batch is finished. In addition, products are generated by cyclic manner. For a given batch, the time between the two product arrivals is equal to the time of execution of the first operation. 


\subsection{Simple intercellular transfer policy}

In this section, we begin by analyzing the policy that will be used facing disruptions caused by machine breakdown. For this reason, we simulate a manufacturing system which is modelled by ARENA software, according to two strategies. The first implies an interruption of the production in the considered cell when one of the machines breaks down. The second strategy consists in applying the intercellular transfer of cell (a) toward cell (b) in case of failure of one machine of the first cell (see Fig. 2).

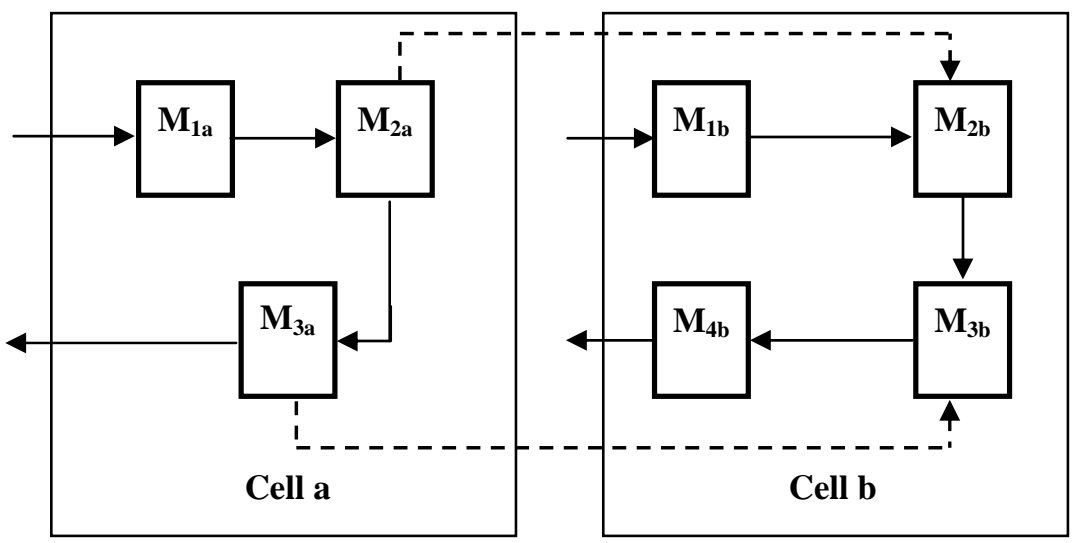

Figure 2: Manufacturing system with simple intercellular transfer.

Table III determines the standby machines to each of the main machines of cell (a).

Table III: Standby machines for simple intercellular transfer.

\begin{tabular}{|c|c|c|c|}
\hline $\begin{array}{c}\text { Principal } \\
\text { machine }\end{array}$ & $\mathbf{M}_{1 \mathbf{a}}$ & $\mathbf{M}_{2 \mathbf{a}}$ & $\mathbf{M}_{\mathbf{3 a}}$ \\
\hline $\begin{array}{c}\text { Standby } \\
\text { machine }\end{array}$ & ---- & $\mathbf{M}_{2 \mathbf{b}}$ & $\mathbf{M}_{3 \mathbf{b}}$ \\
\hline
\end{tabular}

By comparing the results of the two simulations (see Table IV), we can conclude that the intercellular policy gives an improvement of the machine utilization and increases the productivity of cell (a) concerned by the intercellular transfer. However, this policy implies an effect of deterioration on cell (b) of the cellular system. Table IV gives this deterioration in terms of number of pieces produced.

Table IV: Results of the simulation of manufacturing cells with and without a simple intercellular transfer.

\begin{tabular}{|c|c|c|c|c|c|c|c|c|}
\hline \multirow{2}{*}{\multicolumn{2}{|c|}{ Machine }} & \multicolumn{3}{|c|}{ Cell (a) } & \multicolumn{4}{|c|}{ Cell (b) } \\
\hline & & $\mathbf{M}_{1 \mathbf{a}}$ & $\mathbf{M}_{2 \mathbf{a}}$ & $\mathbf{M}_{3 \mathbf{a}}$ & $\mathbf{M}_{1 \mathrm{~b}}$ & $\mathbf{M}_{2 \mathbf{b}}$ & $\mathbf{M}_{3 \mathbf{b}}$ & $\mathbf{M}_{4 \mathrm{~b}}$ \\
\hline \multirow{2}{*}{$\begin{array}{c}\text { Utilization } \\
\text { rate }(\%)\end{array}$} & $\begin{array}{l}\text { Without } \\
\text { transfer }\end{array}$ & 42.96 & 62.81 & 61.5 & 50.54 & 41.76 & 49.36 & 50.44 \\
\hline & With transfer & 45.61 & 64.05 & 64.22 & 49.63 & 43.68 & 49.58 & 49.54 \\
\hline \multirow{2}{*}{$\begin{array}{c}\text { Number of } \\
\text { manufactured } \\
\text { products }\end{array}$} & $\begin{array}{l}\text { Without } \\
\text { transfer }\end{array}$ & \multicolumn{3}{|c|}{30633} & \multicolumn{4}{|c|}{25955} \\
\hline & With transfer & \multicolumn{3}{|c|}{32531} & \multicolumn{4}{|c|}{25490} \\
\hline
\end{tabular}


For this reason another strategy of policy with intercellular transfer will be developed. It implies a better utilization of unexploited resources. This strategy consists in applying an intercellular transfer in case of breakdown between the two cells. Indeed, in addition of the policy of intercellular transfer indicated in table III, this strategy implies that in cases of the breakdown of the machine $\mathrm{M}_{1 \mathrm{~b}}$ of cell (b) product flow in this cell will be redirected toward the replacement machine $\mathrm{M}_{1 \mathrm{a}}$ located in cell (a).

The improvement given by this strategy on the two cells of production is shown in Table V.

Table V: Results of the simulation of manufacturing cells in the case of applying the policy in both cells.

\begin{tabular}{|c|c|c|c|c|c|c|c|c|}
\hline \multirow{2}{*}{\multicolumn{2}{|c|}{ Machine }} & \multicolumn{3}{|c|}{ Cell (a) } & \multicolumn{4}{|c|}{ Cell (b) } \\
\hline & & $\mathbf{M}_{1 \mathbf{a}}$ & $\mathbf{M}_{2 \mathbf{a}}$ & $\mathbf{M}_{3 \mathbf{a}}$ & $\mathbf{M}_{1 \mathbf{b}}$ & $\mathbf{M}_{2 \mathbf{b}}$ & $\mathbf{M}_{3 \mathbf{b}}$ & $\mathbf{M}_{4 b}$ \\
\hline \multirow{2}{*}{$\begin{array}{c}\text { Utilization } \\
\text { rate }(\%)\end{array}$} & $\begin{array}{l}\text { Without } \\
\text { transfer }\end{array}$ & 42.96 & 62.81 & 61.5 & 50.54 & 41.76 & 49.36 & 50.44 \\
\hline & With transfer & 45.43 & 62.38 & 62.44 & 50.59 & 45.18 & 51.54 & 51.53 \\
\hline \multirow{2}{*}{$\begin{array}{c}\text { Number of } \\
\text { manufactured } \\
\text { products }\end{array}$} & $\begin{array}{l}\text { Without } \\
\text { transfer }\end{array}$ & \multicolumn{3}{|c|}{30633} & \multicolumn{4}{|c|}{25955} \\
\hline & With transfer & \multicolumn{3}{|c|}{31656} & \multicolumn{4}{|c|}{26513} \\
\hline
\end{tabular}

\subsection{Double intercellular transfer policy}

This policy consists in applying the double intercellular transfer of cell (a) toward cell (b) in case of breakdown of one machine of the first cell. Table VI determines the standby machines affected to each main machine of cell (a).

Table VI: Standby machines for double intercellular transfer.

\begin{tabular}{|l|c|c|c|}
\hline Principal machine & $\mathbf{M}_{1 \mathbf{a}}$ & $\mathbf{M}_{2 \mathbf{a}}$ & $\mathbf{M}_{3 \mathbf{a}}$ \\
\hline $\begin{array}{l}\text { Primary standby } \\
\text { machine }\end{array}$ & ---- & $\mathbf{M}_{2 \mathbf{b}}$ & $\mathbf{M}_{3 \mathbf{b}}$ \\
\hline $\begin{array}{l}\text { Secondary standby } \\
\text { machine }\end{array}$ & ---- & $\mathbf{M}_{1 \mathbf{b}}$ & ---- \\
\hline
\end{tabular}

Table VII shows the improvement brought by this strategy on the two cells of production in relation to a strategy without intercellular transfer.

Table VII: Results of the simulation of manufacturing cells with and without double intercellular transfer.

\begin{tabular}{|c|c|c|c|c|c|c|c|c|}
\hline \multirow{2}{*}{\multicolumn{2}{|c|}{ Ma }} & \multicolumn{3}{|c|}{ Cell (a) } & \multicolumn{4}{|c|}{ Cell (b) } \\
\hline & & $\mathbf{M}_{1 \mathbf{a}}$ & $\mathbf{M}_{2 \mathbf{a}}$ & $\mathbf{M}_{3 \mathbf{a}}$ & $\mathbf{M}_{1 \mathrm{~b}}$ & $\mathbf{M}_{2 \mathbf{b}}$ & $\mathbf{M}_{3 \mathbf{b}}$ & $\mathbf{M}_{4 b}$ \\
\hline \multirow{2}{*}{$\begin{array}{c}\text { Utilization } \\
\text { rate }(\%)\end{array}$} & $\begin{array}{l}\text { Without } \\
\text { transfer }\end{array}$ & 42.96 & 62.81 & 61.5 & 50.54 & 41.76 & 49.36 & 50.44 \\
\hline & With transfer & 46.08 & 62.56 & 64.7 & 52.53 & 44.58 & 50.6 & 50.45 \\
\hline \multirow{2}{*}{$\begin{array}{c}\text { Number of } \\
\text { manufactured } \\
\text { products }\end{array}$} & $\begin{array}{l}\text { Without } \\
\text { transfer }\end{array}$ & \multicolumn{3}{|c|}{30633} & \multicolumn{4}{|c|}{25955} \\
\hline & With transfer & \multicolumn{3}{|c|}{32845} & \multicolumn{4}{|c|}{25950} \\
\hline
\end{tabular}




\section{DISCUSSION OF RESULTS}

The obtained results in this paper permit to evaluate the policy of intercellular transfer in case of breakdown and to extricate the adequate conditions that justify the utilization of this policy in order to bring an improvement to the cellular production system.

The analysis by simulation of the intercellular transfer policy permitted to make several conclusions. These conclusions are summarized as follows:

- In case of breakdown, intercellular transfer of cell (a) toward cell (b) permits to improve the performance of cell (a). This improvement is noted by the increase of the number of products finished in this cell. On the other hand, a deterioration of the performance of cell (b) is provoked.

- The application of intercellular transfer between the two cells (a) and (b), from (a) toward (b) and from (b) toward (a), gives an improvement of the two cells. It leads to an improvement of the whole production system. It is to emphasize that the improvement of cell (a) in the first case is more important than in the second.

Therefore, if the objective is the improvement of a studied cell of the production system while accepting the deterioration of others, it is necessary to apply only the policy of intercellular transfer on this cell. On the other hand, if the objective is to improve the performance of the different cells of the system, it is necessary to apply the policy of intercellular transfer to the different cells.

By comparing the results shown in Tables IV and VII, we conclude that the double intercellular transfer policy improves the system better than the policy of the simple intercellular transfer. This conclusion confirms the results of previous works [13] showing that the increase of the transfer probability improves the production cell availability.

\section{CONCLUSION}

This paper describes the development of a simulation study to overcome the effect of failure in the cellular manufacturing. We presented a solution facing breakdown machine based on a simple and double intercellular transfer. The proposed solution in this paper confirmed that it is possible to reduce the severity of breakdowns in the cellular manufacturing system and improve the availability of the cells through an intercellular transfer. Moreover, simulation results confirm the analytic results developed by Elleuch et al [13].

Future research needed to investigate the impact of this policy on the cell while analyzing other performance criteria and taking into account the other resources.

\section{ACKNOWLEDGEMENT}

The authors would like to thank Mr. A. Hajji from the Engineering School of Sfax for his help with English language.

\section{REFERENCES}

[1] Vakharia, A. J.; Wemmerlov, U. (1990). Designing a Cellular Manufacturing System: A Materials Flow Approach Based on Operation Sequences, IIE Transaction, Vol. 22, No. 1, 84-97

[2] Sassani, F. (1990). A simulation study on performance improvement of group technology cells, International Journal of Production Research, Vol. 28, No. 2, 293-300

[3] Banerjee, A.; Flynn, B. (1987). A Simulation Study of Some Maintenance Policies in a Group Technology Shop, International Journal of Production Research, Vol. 25, No. 11, 1595-1609 
[4] Smith, A. M.; Hinchiffe, G. R.; Wojtisek, J. E.; Voehl, F. W. (1991). Using Reliability-Centered Maintenance to Support Corporate TQM Objectives, Proceedings of the IEEE Annual Reliability and Maintainability Symposium, 101-107

[5] Iravani, S. M. R.; Duenyas, I. (2002). Integrated Maintenance and Production Control of a Deteriorating Production System, IIE Transactions, Vol. 34, 423-435

[6] Widmer, M.; Solot, P. (1990). Do Not Forget the Breakdowns and the Maintenance Operations in FMS Design Problems!, International Journal of Production Research, Vol. 28, No. 1, 421-430

[7] Burbidge, J. L. (1992). Change to Group Technology: Process Organization is Obsolete, International Journal of Production Research, Vol. 25, No. 5, 1209-1219

[8] Seifoddini, H. (1990). A Probabilitic Model for Machine Cells Formation, Journal of Manufacturing Systems, Vol. 9, No. 1, 69-75

[9] Harhalakis, G.; Proth, J. M.; Xie, X. L. (1990). Manufacturing Cell Design Using Simulated Annealing: An Industrial Application, Journal of Intelligent Manufacturing, Vol. 1, 185-191

[10] Lahoti, A.; Kennedy, W. J. (1991). Analyzing the Effect of Installing Diagnostic Equipment in a Manufacturing Cell, Proceedings of the IEEE Annual Reliability and Maintainability Symposium, $10-14$

[11] Geonwook, J.; Herman, R. L.; Hamid, R. P. (1998). A cellular manufacturing system based on new similarity coefficient which considers alternative routes during machine failure, Computers and Industrial Engineering, Vol. 35, 73-76

[12] Dhouib, K.; Ait-Kadi, D. (1998). Contibution des Politiques Tolerantes aux Fautes à la Disponibilité des Cellules de Production Flexibles, Congrés International JTEA 98, Nabeul, Tunisie

[13] Elleuch, M.; Ben Bacha, H.; Masmoudi, F. (2003). Amélioration de la disponibilité des cellules de production, CPI'2003, Meknes, Morocco

[14] Arena Standard User's Guide, Doc ID ARENAS-UM001C-EN-P, 2002, Rockwell Software Inc. 